\title{
PENYULUHAN KESADARAN MASYARAKAT SEPUTAR KAMPUS UNIVERSITAS BUANA PERJUANGAN KARAWANG MENGENAI DAMPAK SAMPAH SERTA PELATIHAN PEMANFAATAN SAMPAH PLASTIK UNTUK KEGIATAN EKONOMI KREATIF
}

\author{
Oleh : Budi Rismayadi, SE.,MM
}

\section{Pendahuluan}

Kabupaten Karawang dengan pertumbuhan ekonomi dan pembangunan yang demikian pesat diberbagai sector telah merubah pola ekonomi masyarakat dan permasalahannya menjadi lebih kompleks, berbagai kebutuhan masyarakat di Karawang sangat tergantung kepada penggunaan bahan yang bersifat anorganik dan material lain dari produk dari pengolahan bahan kimia seperti sterofoam, plastic, fiber dan lain sebagainya. Hal tersebut tentu saja menyebabkan muncul permasalahan dimana timbunan sampah plastic dan produk anorganik lainnya menjadi semakin besar setiap tahunnya.

Data yang diperoleh dari dinas lingkungan hidup dan kebersihan kabupaten karawang menyatakan bahwa pada tahun 2016 volume sampah plastik di tempat pembuangan sampah Jalupang rata rata mencapai 1.100 meter kubik setiap harinya, bahkan pada saat menjelang hari raya biasanya volume sampah diperkirakan mengalami kenaikan hingga 45\%. Sementara dari laporan yang disampaikan DLKH diprediksi bahwa peningkatan volume sampah plastic setiap tahun meningkat sebesar 5\%. Hal ini sejalan dengan peryataan dari kementrian lingkungan hidup dan kehutanan (KLHK) bahwa data menunjukkan sampah yang dihasilkan di Indonesia pada tahun 2017 mencapai 65,8 juta ton, ini berarti jika tidak dilakukan upaya untuk mengantisipasi sampah akan menyebabkan timbul gunungan sampah di beberapa daerah yang menyebabkan persoalan yang jauh lebih besar lagi.

Limbah plastik merupakan masalah yang sudah dianggap serius bagi pencemaran lingkungan khususnya bagi pencemaran tanah. Karena sifatnya yang merupakan bahan anorganik sehingga plastic tidak bisa terurai oleh bakteri dan membutuhkan waktu yang cukup lama untuk dapat terurai, sehingga sifatnya ini mampu menyebabkan turunnya tingkat kesuburan tanah, selain itu penggunaan plastic oleh warga masyarakat juga menjadi salah satu permasalahan yang cukup sulit untuk dikendalikan.

Selain itu plastic juga digunakan sebagai media untuk menampung berbagai jenis barang termasuk bahan kimia yang berbahaya, wilayah Kabupaten Karawang yang memiliki banyak kawasan industry tidak jarang menghasilkan limbah plastic yang mengandung bahan 
beracun dan berbahaya, sehingga seringkali ditemukan laporan mengenai pencemaran lingkungan yang disebabkan dari pembuangan limbah yang mengandung B3, dan beberapa waktu lalu ditemukan tumpukan sampah plastic di kecamatan pangkalan yang diduga mengandung B3 sehingga kepolisian turun tangan melakukan pengujian terhadap timbunan sampah plastic tersebut.

Berbagai langkah dilakukan oleh pemerintah untuk mengendalikan dampak dari sampah plastic, dan alangkah baiknya jika limbah plastik tersebut dapat digunakan lagi dengan secara bijaksana dengan cara mendaur ulang dan dijadikan produk baru, dan ini tentu saja membutuhkan keahlian dan keterampilan khusus dari warga masyarakat untuk dapat mengubah sampah plastic menjadi produk lain. Upaya pengelolaan daur ulang sampah plastik telah banyak dilakukan oleh pemerintah, seperti dengan menyediakan tempat sampah yang sudah dipecah menjadi beberapa kategori sampah (sampah basah dan sampah kering). Akan tetapi strategi ini masih belum memberikan hasil yang signifikan dalam reduksi jumlah sampah plastik.

Namun demikian dianggap bahwa cara yang dilakukan saat ini belum sepenuhnya berjalan efektif. Masih banyak masyarakat yang membuang sampah tidak berdasarkan kategori sampah. Peningkatan pemahaman kepada masyarakat tentang bagaimana bahayanya sampah plastic bagi pencemaran lingkungan perlu dilakukan secara terus menerus baik dengan sosialisasi secara langsung maupun tidak langsung. Seperti yang diungkapkan oleh Vesilind et al (2003) menyatakan bahwa dalam implementasi sebuah manajemen/pengelolaan sampah dalam sebuah komunitas, hal pertama yang dilakukan adalah dengan melakukan reduksi sampah langsung pada sumber penghasil sampah. Dalam kasus tertentu yang menjadi sumber penghasil sampah plastic tentu saja sangat banyak, termasuk rumah tangga masyarakat yang memberikan sumbangan dalam tingginya sampah plastic di Kabupaten Karawang.

Dibutuhkan sebuah cara efektif agar dalam aktivitas ini, sampah plastik yang terkumpul sudah terpisah berdasarkan kategori jenis plastik, sehingga proses daur ulang di tingkat selanjutnya dapat dilakukan lebih efisien. Pengelolaan daur ulang sampah plastik yang ergonomis dan terintegrasi dengan baik akan dapat membantu kegiatan atau program strategis dalam upaya pengurangan jumlah sampah plastik yang efektif.

Dalam proses suatu sistem sedikitnya ada 6 aspek yang perlu diperhatikan yaitu secara teknis, ekonomis, ergonomis, sosio-kultural, bisa dipertanggungjawabkan, hemat energi, dan turut melestarikan lingkungan (Manuaba, 2004). Artinya bahwa perlu dilakukan secara konsisten perlakuan terhadap masyarakat dalam memahami mengenai penanggulangan sampah plastic 
yang secara efektif akan dapat membantu berjalannya mekanisme dan aturan pemerintah daerah dalam penanggunalan sampah terutama plastic, sehingga akan dapat ditekan resiko penambahan volume sampah masyarakat dari bahan plastic.

Dengan memperhatikan keenam aspek atau kriteria inilah yang akan digunakan dalam penyusunan manajemen/pengelolaan daur ulang sampah plastic, penelitian yang dilakukan oleh masyarakat ditujukan kepada bagaimana penggunaan metode strategi manajemen/pengelolaan daur ulang sampah plastik yang efektif dengan melibatkan masyarakat (sumber penghasil sampah) secara langsung dan lembaga-lembaga informal daur ulang yang terkait, disertai dengan pemilihan teknologi dan fasilitas yang efisien dan ergonomis guna meningkatkan pemberdayaan masyarakat, pada khusunya adalah rumah tangga sebagai fokus utama dalam berbagai kajian penelitian. Sehingga pada akhirnya dari hasil penelitian tersebut dapat memberikan alternatif teknologi dalam proses daur ulang sehingga dapat meningkatkan produktivitas kerja serta dapat digunakan sebagai acuan dalam strategi pengelolaan sampah plastik yang terintegrasi guna peningkatan pemberdayaan masyarakat dan diharapkan dapat menekan jumlah sampah plastic

Upaya lain yang dilakukan oleh masyarakat adalah dengan memberikan dan meningkatkan berbagai pelatihan bagaimana menghasilkan produk dari pemanfaatan limbah plastic, dan ini dianggap sebagai salah satu alternative dalam upaya menekan penyebaran sampah plastic, upaya ini telah banyak dikembangkan oleh masyarakat dan berbagai organisasi, sehingga beberapa produk hasil kreatifitas masyarakat ini memiliki nilai ekonomis yang lebih besar.

Dari uraian tersebut di atas, maka perlu dilakukan upaya alternative dalam memberikan penyuluhan dan sosialisasi kepada masyarakat mengenai demikian pentingnya peran mereka dalam mengendalikan penyebaran sampah platik dilingkungan yang dapat merugikan dan merusak lingkungan, upaya ini dapat dilakukan dengan memberikan bekal keterampilan dan keahlian kepada masyarakat dalam mengubah limbah plastic menjadi berbagai produk yang bermanfaat yang tujuannya adalah mengurangi pembuangan sampah plastic.

\section{Maksud dan tujuan}

Maksud dilaksanakannya kegiatan ini antara lain untuk :

1. Bagaimana pengetahuan masyarakat dilingkar kampus UBP Karawang tentang bahaya sampah plastic bagi pencemaran lingkungan 
2. Bagaimana langkah yang telah dilakukan oleh pemerintah daerah dalam menangani permasalahan sampah dimasyarakat

3. Memberikan pelatihan menghasilkan produk berbahan dasar dari limbah plastic

Sedangkan tujuan dari dilaksanakannya kegiatan ini antara lain :

1. Untuk mengetahui bagaimana pengetahuan masyarakat dilingkar kampus UBP Karawang mengenai bahaya sampah plastic bagi pencemaran lingkungan

2. Untuk mengetahui bagaimana langkah yang telah dilakukan oleh pemerintah daerah dalam menangani permasalahan sampah di masyarakat

3. Untuk memberikan pelatihan dan keterampilan masyarakat dalam menghasilkan produk dari bahan limbah plastic

\section{Sasaran Kegiatan}

Sasaran dari pelaksanaan kegiatan ini antara lain :

1. Timbul kesadaran dari masyarakat tentang bahaya ampah plastic bagi lingkungan dan pentingnya budaya membuang sampah pada tempat yang telah disediakan

2. Ibu-ibu rumah tangga mampu memilah sampah plastic dari limbah rumah tangganya sehingga dapat mempermudah dalam pemilahan sampah organic dan anorganik

3. Masyarakat memiliki keahlian dan keterampilan dalam menghasilkan produk dari bahan limbah plastic sehingga diharapkan dapat menekan peningkatan volume sampah plastik

\section{Materi}

\section{Sejarah Plastik}

Sejak tahun 1950-an plastik menjadi bagian penting dalam hidup manusia. Plastik digunakan sebagai bahan baku kemasan, tekstil, bagian-bagian mobil dan alat-alat elektronik. Dalam dunia kedokteran, plastik bahkan digunakan untuk mengganti bagian-bagian tubuh manusia yang sudah tidak berfungsi lagi. Pada tahun 1976 plastik dikatakan sebagai materi yang paling banyak digunakan dan dipilih sebagai salah satu dari 100 berita kejadian pada abad ini.

Plastik pertama kali diperkenalkan oleh Alexander Parkes pada tahun 1862 di sebuah ekshibisi internasional di London, Inggris. Plastik temuan Parkes disebut parkesine ini dibuat 
dari bahan organik dari selulosa. Parkes mengatakan bahwa temuannya ini mempunyai karakteristik mirip karet, namun dengan harga yang lebih murah. Ia juga menemukan bahwa parkesine ini bisa dibuat transparan dan mampu dibuat dalam berbagai bentuk. Sayangnya, temuannya ini tidak bisa dimasyarakatkan karena mahalnya bahan baku yang digunakan.

Pada akhir abad ke-19 ketika kebutuhan akan bola biliar meningkat, banyak gajah dibunuh untuk diambil gadingnya sebagai bahan baku bola biliar. Pada tahun 1866, seorang Amerika bernama John Wesley Hyatt, menemukan bahwa seluloid bisa dibentuk menjadi bahan yang keras. Ia lalu membuat bola biliar dari bahan ini untuk menggantikan gading gajah. Tetapi, karena bahannya terlalu rapuh, bola biliar ini menjadi pecah ketika saling berbenturan.

Bahan sintetis pertama buatan manusia ditemukan pada tahun 1907 ketika seorang ahli kimia dari New York bernama Leo Baekeland mengembangkan resin cair yang ia beri nama bakelite. Material baru ini tidak terbakar, tidak meleleh dan tidak mencair di dalam larutan asam cuka. Dengan demikian, sekali bahan ini terbentuk, tidak akan bisa berubah. Bakelite ini bisa ditambahkan ke berbagai material lainnya seperti kayu lunak.

Tidak lama kemudian berbagai macam barang dibuat dari bakelite, termasuk senjata dan mesin-mesin ringan untuk keperluan perang. Bakelite juga digunakan untuk keperluan rumah tangga, misalnya sebagai bahan untuk membuat isolasi listrik.

Rayon, suatu modifikasi lain dari selulosa, pertama kali dikembangkan oleh Louis Marie Hilaire Bernigaut pada tahun 1891 di Paris. Ketika itu ia mencari suatu cara untuk membuat sutera buatan manusia dengan cara mengamati ulat sutera. Namun, ada masalah dengan rayon temuannya ini yaitu sangat mudah terbakar. Belakangan masalah ini bisa diatasi oleh Charles Topham.

\section{Demam Plastik}

Tahun 1920 ditandai dengan demam plastik. Wallace Hume Carothers, ahli kimia lulusan Universitas Harvard yang mengepalai DuPont Lab, mengembangkan nylon yang pada waktu itu disebut Fiber 66. Fiber ini menggantikan bulu binatang untuk membuat sikat gigi dan stoking sutera. Pada tahun 1940-an nylon, acrylic, polyethylene, dan polimer lainnya menggantikan bahan-bahan alami yang waktu itu semakin berkurang. 
Inovasi penting lainnya dalam plastik yaitu penemuan polyvinyl chloride (PVC) atau vinyl. Ketika mencoba untuk melekatkan karet dan metal, Waldo Semon, seorang ahli kimia di perusahaan ban B.F. Goodrich menemukan PVC. Semon juga menemukan bahwa PVC ini adalah suatu bahan yang murah, tahan lama, tahan api dan mudah dibentuk.

Pada tahun 1933, Ralph Wiley, seorang pekerja lab di perusahaan kimia Dow, secara tidak sengaja menemukan plastik jenis lain yaitu polyvinylidene chloride atau populer dengan sebutan saran. Saran pertama kali digunakan untuk peralatan militer, namun belakangan diketahui bahwa bahan ini cocok digunakan sebagai pembungkus makanan. Saran dapat melekat di hampir setiap perabotan seperti mangkok, piring, panci, dan bahkan di lapisan saran sendiri. Tidak heran jika saran digunakan untuk menyimpan makanan agar kesegaran makanan tersebut terjaga.

Pada tahun yang sama, dua orang ahli kimia organik bernama E.W. Fawcett dan R.O. Gibson yang bekerja di Imperial Chemical Industries Research Laboratory menemukan polyethylene. Temuan mereka ini mempunyai dampak yang amat besar bagi dunia. Karena bahan ini ringan serta tipis, pada masa Perang Dunia II bahan ini digunakan sebagai pelapis untuk kabel bawah air dan sebagai isolasi untuk radar.

Pada tahun 1940 penggunaan polyethylene sebagai bahan isolasi mampu mengurangi berat radar sebesar 600 pounds atau sekitar $270 \mathrm{~kg}$. Setelah perang berakhir, plastik ini menjadi semakin populer. Saat ini polyethylene digunakan untuk membuat botol minuman, jerigen, tas belanja atau tas kresek, dan kontainer untuk menyimpan makanan.

Kemudian pada tahun 1938 seorang ahli kimia bernama Roy Plunkett menemukan teflon. Sekarang teflon banyak digunakan untuk melapisi peralatan memasak sebagai bahan antilengket.

Selanjutnya, seorang insinyur Swiss bernama George de Maestral sangat terkesan dengan suatu jenis tumbuhan yang menggunakan ribuan kait kecil untuk menempelkan dirinya. Lalu pada tahun 1957 de Maestral meniru tumbuhan tersebut untuk membuat Velcro atau perekat dari bahan nylon.

Mengenal sampah plastik dan pengolahannya 
Hampir setiap orang pasti tidak akan terlepas dari yang namanya bahan plastik dalam aktivitasnya sehari-hari. Ya, memang plastik telah menjadi komponen penting dalam kehidupan modern saat ini dan peranannya telah menggantikan kayu dan logam mengingat kelebihan yang dimilikinya antara lain ringan dan kuat, tahan terhadap korosi, transparan dan mudah diwarnai, serta sifat insulasinya yang cukup baik.

Sifat-sifat bahan plastik inilah yang membuatnya sulit tergantikan dengan bahan lainnya untuk berbagai aplikasi khususnya dalam kehidupan sehari-hari mulai dari kemasan makanan, alat-alat rumah tangga, mainan anak, elektronik sampai dengan komponen otomotif. Peningkatan penggunaan bahan plastik ini mengakibatkan peningkatan produksi sampah plastik dari tahun ke tahun. Sebagai gambaran konsumsi plastik di Indonesia mencapai $10 \mathrm{~kg}$ perkapita pertahun, sehingga dapat diprediksikan sebesar itulah sampah plastik yang dihasilkan.

Tetapi tanpa disadari, plastic merupakan jenis sampah yang paling sulit untuk diurai dan sekaligus yang paling banyak mencemari lingkungan. Untuk mengurai sampah plastik bekas botol air mineral saja, setidaknya dibutuhkan waktu sampai 500 tahun. Tidak hanya di darat, pencemaran limbah plastic yang ada di laut juga bisa mengganggu keseimbangan ekosistem, yaitu membuat laut tercemar dan banyak hewan laut yang tertelan sampah plastic sehingga menyebabkan kematian.

Seperti telah kita ketahui bersama bahwa plastik sangat sulit terurai dalam tanah, membutuhkan waktu bertahun-tahun dan ini akan menimbulkan permasalahan tersendiri dalam penanganannya. Pembuangan di Tempat Pembuangan Akhir (TPA) sampah bukanlah solusi yang cukup bijak dalam pengelolaan sampah plastik ini. Peranan para pemulung dalam mengurangi timbunan sampah plastik patut mendapat apresiasi meskipun ini tidak bisa menghilangkan seratus persen sampah plastik yang ada. Perlu adanya manajemen sampah plastik mulai dari lingkungan terkecil yaitu rumah tangga hingga skala besar meliputi kawasan kota yang dikelola oleh pemerintah kota atau daerah setempat. Untuk memudahkan pengelolaan sampah plastik pada skala rumah tangga, maka perlu adanya pemahaman tentang jenis-jenis plastik, kandungan materialnya, hingga dampaknya terhadap lingkungan sehingga diharapkan terbentuk manajemen pengelolaan yang tepat.

Berikut adalah kode dari material plastic yang dikeluarkan oleh The Society of Plastic Industry pada tahun 1998 di Amerika Serikat dan digunakan juga oleh lembaga pengembangan system seperti ISO (International Organization for Standardization) 


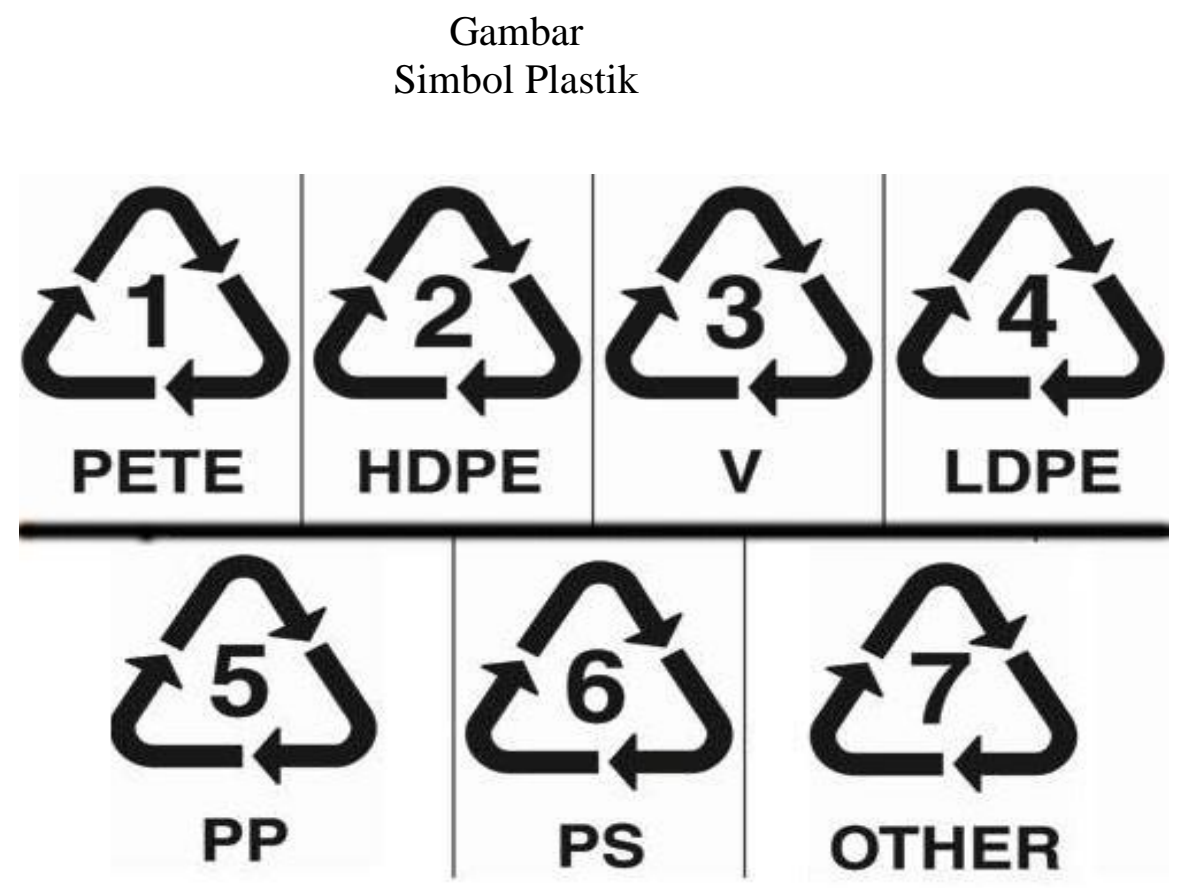

Sumber Gambar : www.google.com

Untuk menjelaskan mengenai kode tersebut di atas dapat diuraikan sebagai berikut :

\section{Polyethlene Etilen Terephalate (PET)}

Pada PET atau PETE (Polyethlene Etilen Terephalate) biasanya logo ini tertera dengan angka 1 seperti gambar di atas, kode ini dipakai untuk botol plastic berwarna jernih atau transparan atau tembus pandang, contohnya adalah botol air mineral, botol minuman jus dan hamper banyak minuman jenis lainnya. Kemasan botol dengan kode yang seperti ini sebagikan dipakai hanya sekali saja, karena apabila terlalu sering digunakan untuk menyimpan air hangat atau air panas dapat mengakibatkan lapisan polimer pada botol akan meleleh dan mengeluarkan zat karsinogenik yang dalam jangka panjang akan menyebabkan muncul penyakit kanker.

Bahan PTE ini cukup berbahaya bagi pekerja yang berhubungan dengan pengolahan daur ulang botol PETE. Karena pembuatan PETE menggunakan senyawa antimony trioksida, senyawa ini apabila dihirup dapat mengakibatkan iritasi kulit dan saluran pernafasan, sedangkan bagi wanita senyawa ini dapat menimbulkan masalah yang cukup serius mulai dari persoalan 
menstruasi yang bermasalah, keguguran bagi ibu hamil dan keterlambatan pertumbuhan anak pada usia hingga 12 bulan.

\section{Hige Density Polyethylene (HDPE)}

Pada kemasan berkode 2 dengan nama HDPE ini biasanya dipakai untuk botol susu yang berwarna putih susu, tupperware, galon air minum, kursi lipat dan lain-lain. Botol plastic jenis HDPE memiliki sifat bahan yang lebih kuat, keras, buram dan lebih tahan lama terhadap suhu yang tinggi.

HDPE merupakan salah satu bahan plastic yang aman untuk digunakan karena kemampuan untuk mencegah reaksi kimia antara kemasan plastic berbahan HDPE dengan makanan/minuman yang dikemasnya. Sama seperti PET, HDPE juga direkomendasikan hanya sekali pemakaian saja, karena pelepasan senyawa antimony trioksida terus meningkat seiring waktu, jenis ini juga dapat di daur ulang kembali menjadi bahan lantai ubin, pipa dan lainnya.

\section{Polyvinyl Chloride (PVC)}

Tertulis (kadang berwarna merah) dengan angka 3 ditengahnya, tulisan $\mathrm{V}$ itu berarti PVC (Polyvinyl Chloride), yaitu jenis plastic yang paling sulit di daur ulang, ini biasanya ditemukan pada plastic pembungkus (cling wrap), dan botol-botol. Reaksi yang terjadi antara PVC dengan makanan yang dikemas dengan menggunakan plastic jenis ini berpotensi mengidap penyakit berbahaya terutama bagi kesehatan ginjal dan hati, bahan ini akan mengeluarkan racun apabila dibakar atau terkena suhu panas. PVC tidak diperbolehkan digunakan dalam menyiapkan makanan atau kemasan makanan.

\section{Low Density Polyethylene (LDPE)}

LDPE yaitu plastic umumnya berwarna cokelat dan merupakan jenis thermoplastic atau dibuat dari minyak bumi, biasanya digunakan untuk tempat makanan, plastic kemasan, botol yang relative lebih lunak, pakaian dan mebeul serta produk lainnya

Sifat mekanisnya lebih kuat, tembus pandang, fleksibel dan permukaannya agak berlemak, pada suhu 60 derajat sangat resisten terhadap reaksi kimia, daya proteksi terhadap uap air tergolong baik, dapat di daur ulang serta baik untuk barang yang memerlukan fleksibilitas tapi kuat 
Barang barang berbahan LDPE ini sulit dihancurkan, tetapi baik untuk tempat makanan karena reaksi kimia antara makanan dengan kemasan dari LDPE tidak mudah bereaksi sehingga bahan ini relative mudah didaur ulang.

\section{Polyproplene}

Plastic dengan kode seperti ini biasanya memiliki karakteristik botol yang agak transparan seperti berawan, polipropilen jenis plastic yang cukup kuat dan ringan dengan daya tembus uap yang rendah, ketahanan yang baik terhadap lemak dan stabil terhadap suhu yang cukup tinggi.

Jenis plastic ini merupakan bahan plastic terbaik yang sering digunakan untuk tempat makanan dan minuman yang paling penting terutama untuk botol minuman untuk bayi. Jika ingin menggunakan botol untuk menyimpan makanan dan minumna sebaiknya menggunakan botol atau wadah dengan kode angka 5 tersebut sehingga relative lebih aman dan terjamin kualitas makanan dan minuman tetap dalam kondisi baik.

Selain itu bahan plastic jenis ini juga mudah untuk digunakan sebagai bahan daur ulang, sehingga banyak masyarakat memanfaatkan plastic jenis ini untuk menghasilkan berbagai produk baru yang lebih aman dan terjaga.

\section{Polystyrene (PS)}

Polistirena pertama kali dibuat pada 1839 oleh Eduard Simon, seorang apoteker Jerman. Ketika mengisolasi zat tersebut dari resin alami, dia tidak menyadari apa yang dia telah temukan. Seorang kimiawan organik Jerman lainnya, Hermann Staudinger, menyadari bahwa penemuan Simon terdiri dari rantai panjang molekul stirena, yang adalah sebuah polimer plastik.

Polistirena padat murni adalah sebuah plastik tak berwarna, keras dengan fleksibilitas yang terbatas yang dapat dibentuk menjadi berbagai macam produk dengan detail yang bagus. Penambahan karet pada saat polimerisasi dapat meningkatkan fleksibilitas dan ketahanan kejut. Polistirena jenis ini dikenal dengan nama High Impact Polystyrene (HIPS). Polistirena murni yang transparan bisa dibuat menjadi beraneka warna melalui proses compounding. Polistirena banyak dipakai dalam produk-produk elektronik sebagai casing, kabinet dan komponen- 
komponen lainya. Peralatan rumah tangga yang terbuat dari polistirena, a.l: sapu, sisir, baskom, gantungan baju, ember.

Bahan jenis ini hendaknya dihindari untuk digunakan sebagai bahan menyimpan makanan dan minuman karena jenisnya yang berbahaya untuk manusia, sebagian peneliti menyampaikan bahwa penggunaan plastic jenis ini untuk menyimpan makanan dan minuman akan beresiko mengganggu kesehatan otak, hormone estrogen pada wanita, menyebabkan masalah pada reproduksi dan pertumbuhan system syaraf.

Dampak yang lainnya adalah bagi kesehatan manusia, kandungan yang terdapat pada styrofoam seperti benzen, carsinogen, dan styrene akan bereaksi dengan cepat begitu makanan dimasukkan kedalam styrofoam. Uap panas dari makanan akan memicu rekasi kimia ini terjadi lebih cepat, misalnya saja zat benzen yang bila sudah bereaksi dan masuk kedalam tubuh dan masuk kedalam jaringan darah dan terakumulasi selama bertahun tahun akan menimbulkan kerusakan pada sum sum tulang belakang, menimbulkan anemia dan bahkan mengurangi produksi sel darah merah yang sangat dibutuhkan tubuh untuk mengankut saripati makana dan oksigen ke seluruh tunuh. Bila jumlah sel darah merah kita semakin berkurang akibat dari reaksi styrofoam ini maka tubuh kita akan mengalmai beberapa gejala yang kurang wajar. Lalu zat yang tidak kalah bahayanaya adalah carsinogen yang dapat mengakibatkan kanker, carsinoge akan lebih berbahaya bila pemakai wadah styrofoam atau plastik digunakan berulang ulang karena carsinogen mudah larut. Lalu styrene pada penelitian di New Jersey ditemukan 75\% ASI (air susu ibu) terkontaminasi styrene. Hal ini terjadi akibat si ibu menggunakan wadah styrofoam saat mengonsumsi makanan. Penelitian yang sama juga menyebutkan bahwa styrene bisa bermigrasi ke janin melalui plasenta pada ibu-ibu yang sedang mengandung. Terpapar dalam jangka panjang, tentu akan menyebabkan penumpukan styrene dalam tubuh. Akibatnya bisa muncul gejala saraf, seperti kelelahan, gelisah, sulit tidur, dan anemia.

Salah satu jenis polistirena yang cukup populer di kalangan masyarakat produsen maupun konsumen adalah polistirena foam. Polistirena foam dikenal luas dengan istilah styrofoam yang seringkali digunakan secara tidak tepat oleh publik karena sebenarnya styrofoam merupakan nama dagang yang telah dipatenkan oleh perusahaan Dow Chemical. Oleh pembuatnya Styrofoam dimaksudkan untuk digunakan sebagai insulator pada bahan konstruksi bangunan.

Polistirena foam dihasilkan dari campuran $90-95 \%$ polistirena dan 5-10\% gas seperti nbutana atau n-pentana. Polistirena foam dibuat dari monomer stirena melalui polimerisasi suspensi pada tekanan dan suhu tertentu, selanjutnya dilakukan pemanasan untuk melunakkan 
resin dan menguapkan sisa blowing agent. Polistirena foam merupakan bahan plastik yang memiliki sifat khusus dengan struktur yang tersusun dari butiran dengan kerapatan rendah, mempunyai bobot ringan, dan terdapat ruang antar butiran yang berisi udara yang tidak dapat menghantar panas sehingga hal ini membuatnya menjadi insulator panas yang sangat baik.

Polistirena foam begitu banyak dimanfaatkan dalam kehidupan, tetapi tidak dapat dengan mudah direcycle sehingga pengolahan limbahnya harus dilakukan secara benar agar tidak merugikan lingkungan. Pemanfaatan polistirena bekas untuk bahan aditif dalam pembuatan aspal polimer merupakan salah satu cara meminimalisir limbah tersebut.

\section{Other}

Khusus plastic dengan kode 1,3,6 dan 7 (polycarbonate) seluruhnya memiliki bahaya secara kimiawi, namun demikian bukan berarti bahwa plastic dengan kode lain secara utuh aman, namun perlu dipelajari lebih jauh lagi, maka jika kita harus menggunakan plastic hendaknya menggunakan plastic dengan kode 2,4,5 dan 7 kecuali polycarbonate, umumnya plastic polycarbonate digunakan untuk produk lain yang tidak bersentuhan dengan makanan, seperti pembuatan atap rumah dan lain lain.

Berikut ini gambar yang menjelaskan mengenai fungsi plastic untuk berbagai kebutuhan rumah yang relative baik untuk digunakan sebagai wadah untuk menyimpan makanan dan minuman

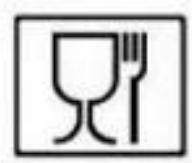

1

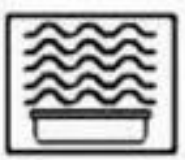

2

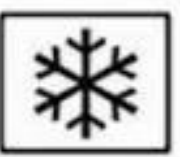

3

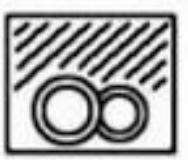

4

a. Gambar pertama yaitu sendok dan garpu, berarti wadah terebut aman bagi makanan

b. Gambar kedua bergambar gelombang radiasi yang menunjukkan bahwa wadah tersebut dapat digunakan dalam microwafe

c. Gambar ketiga mirip dengan serpihan salju, berarti bahwa wadah tersebut dapat dimasukkan dalam freezer

d. Sedangkan gambar piring dengan garis seperti hujan menunjukkan bahwa wadah tersebut dapat diletakkan di dalam mesin pencuci piring 
Setelah mengenali lambing tersebut, ada baiknya kita mulai memperhatikan wadah yang kita miliki agar tidak salah menggunakannya, karena penggunaan yang salah bukan saja merusak lingkungan tapi juga dapat merusak dan berbahaya bagi kesehatan manusia

\section{Catatan :}

- Jika penggunaan plastic dengan bahan berbahaya seperti polycarbonate tidak dapat dicegah, maka jangan menyimpan makanan dan minuman dalam keadaan panas diatas plastic tersebut.

- Hindari penggunaan botol plastic untuk menyimpan air minum, jika penggunaan plastic botol berbahan PET (kode 1) dan HDPE (kode 2) tidak dapat dicegah, gunakanlah hanya sekali pakai saja dan segera dihabiskan karena pelepasan senyawa antimony trioksida terus meningkan seiring waktu, bahan alternative lain yang lebih aman adalah dengan menggunakan wadah botol dari stainless steel atau bahan kaca.

- Cegahlah memanaskan makanan yang dikemas dalam plastic, khususnya pada microwace oven, yang dapat mengakibatkan zat kimia yang terdapat dalam plastic terebut terlepas dan bereaksi dengan makanan lebih cepat. Hal ini pun dapat terjadi bila kemasan plastic digunakan untuk mengemas makanan berminyak atau berlemak.

- Bungkuslah terlebih dahulu makanan dengan menggunakan daun pisang atau kertas sebelum dibungkus dengan plastic pembungkus ketika akan dipanaskan

- Cobalah untuk menggunakan kemasan berbahan kain untuk membawa sayuran, makanan ataupun belanjaan dan gunakanlah kemasan berbahan stainless steel atau kaca untuk menyimpan makanan atau minuman

- Cegahlah penggunaan piring dan alat makan plastic untuk memasak, gunakanlah alat makan berbahan stainless steel, kaca, keramik dan kayu yang relative lebih aman

- Jika kita sering membeli makanan gorengan dipinggir jalan, usahakan tidak langsung dimasukkan ke dalam kantong keresek, karena zat pewarna hitam yang terkandung dalam plastic itu apabila terkena suhu panas akan terurai dan terdegradasi menjadi zat radikal beracun yang berbahaya untuk kesehatan manusia dan mampu menyebabkan sel kanker di dalam tubuh menjadi tidak terkontrol

- Hindari penggunaan botol plastic (air mineral secara berulang-ulang untuk tempat minum) 
- Terapkan, sebarkan dan ajaklah setiap keluarga dan anggota masyarakat diseputar lingkungan agar mengetahui bagaimana menggunakan plastic secara lebih bijaksana

\section{Cara Mudah Memanfaatkan Sampah Plastik}

Artikel daur ulang plastik kali ini akan membahas tentang bagaimana cara yang tepat dan mudah untuk memanfaatkan sampah plastik yang ada di sekitar kita. Artikel daur ulang plastik ini tidak hanya bertujuan untuk memperkenalkan bagaimana cara mengelola sampah tetapi juga mengenal pengertian plastic lebih dalam sehingga tidak membuat Anda bingung. Pertama mari kita kenali lebih dekat pengertian sampah plastik. Sampah plastic atau plastic sendiri sudah menjadi bahan yang tidak tergantikan di kehidupan masyarakat modern. Modernitas dan plastic seperti satu kesatuan yang saling terkait. Di dalam kehidupan sehari-hari selalu memanfaatkan plastic, entah untuk membungkus makanan, berbelanja, dan lain sebagainya.

Artikel daur ulang plastik kali ini juga akan mengupas tentang cara memanfaatkan sampah plastik. Memanfaatkan limbah plastic yang selama ini dianggap merusak ternyata bisa menyelamatkan lingkungan serta memberikan keuntungan materiil. Anda pastinya sudah mulai menyadarai bahwa akhir-akhir ini banyak sekali produk yang terbuat dari sampah yang mempunyai nilai seni dan nilai jual yang cukup tinggi. Bisnis plastic bahkan sudah mulai merambah pesat di setiap daerah. Bahkan usaha rumahan pengelolaan sampah saja bisa menghasilkan omset sampai puluhan juta rupiah. Cobalah tengok di sekitar Anda, ada banyak sampah plastik kemasan pewangi pakaian, detergen, shampoo, kemasan kopi, snack, dan lain sebagainya yang bisa Anda manfaatkan menjadi bentuk tas belanja yang unik atau barang yang lain. Bisakah Anda bayangkan berapa banyak sampah plastic yang bisa Anda hemat dengan membuat dan memakai tas hasil daur ulang ini? Penyelamatan lingkungan bisa dimulai dari diri kita sendiri.

Artikel daur ulang plastik kali ini tidak hanya akan memberikan contoh hasil kerajinan tangan dari plastic yang bisa Anda buat, misalnya tempat pensil, kotak tisu, gantungan baju, celengan, tirai, lukisan kolase plastic, dan lain sebagainya. Setiap produk yang Anda hasilkan bisa Anda buat dengan nilai seni yang tinggi menggunakan perpaduan bahan daur ulang dengan aksesoris lain sebagai pendukung. Sehingga selain berdaya guna juga menghasilkan keuntungan yang tidak sedikit ketika Anda pasarkan ke luar. 


\section{Pengolahan limbah plastik ramah lingkungan}

Cara pengolahan limbah plastik masih menjadi pembahasan hangat dalam setiap pertemuan tentang lingkungan hidup. Dimana limbah plastik merupakan sampah yang tidak bisa diurai oleh tanah. Sehingga akan selalu memiliki ancaman terhadap pencemaran lingkungan. Banyak seminar-seminar yang membahasa tentang betapa seriusnya kekhawatiran tentang limbah plastik ini. Dan harapan kami, generasi yang sekarang dan yang akan datang dapat lebih memahami tentang pengolahan limbah plastik ini.

\section{Gambar}

Pengelolaan Sampah Terpadu

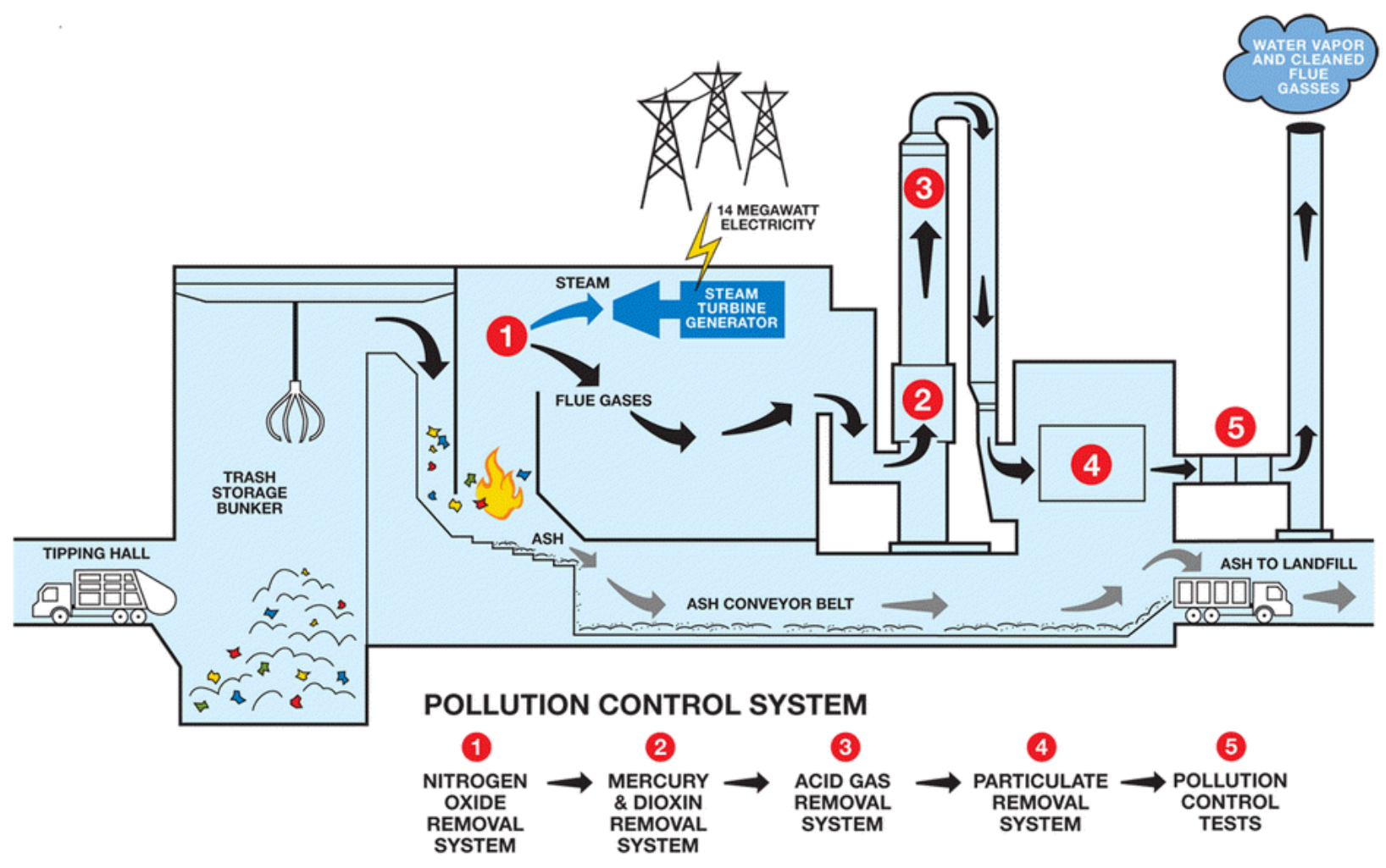

Sumber Gambar : https://g8penyuluhan2016.wordpress.com/

Ada beberapa ide untuk menangani limbah plastik, yaitu diantaranya :

1. Melakukan daur ulang sampah plastik dengan cara memisahkan partikel-partikel plastik hingga terciptanya produk baru. Plastik daur ulang biasanya akan dirubah bentuk menjadi biji 
plastik, botol minuman, dan produk baru dengan bentuk baru yang lainnya. Hampir disetiap negara selalu berupaya melakukan proyek besar dalam melakukan daur ulang sampah plastik.

2. Dengan menggunakan mesin incinerators untuk mendaur ulang limbah plastik. Sebagian negara menggunakan mesin ini untuk mengolah sampah plastik yang tidak teruarai. Semua limbah plastik dibakar menggunakan incinerators. Namun ada dampak buruk jika menggunakan metode ini. Yaitu, timbulnya pencemaran atau polusi udara. Namun seiring berjalannya waktu, para developer telah bekerja keras untuk mengurangi dampak pulusi udara yang ditimbulkan.

3. Untuk mengurangi dampak dari limbah plastik, sebagian besar negara di dunia telah melarang penggunaan produk plastik tertentu. Hal ini untuk mengurangi rasa ketergantungan terhadap produk palstik. Dan menggantikannya dengan produk yang lebih ramah lingkungan.

4. Menggunakan tas dari bahan kertas atau dari bahan lainnya untuk berbelanja. Sehingga dapat mengurangi pemakaian plastik di dalam kehidupan sehari-hari.

5. Untuk mengurangi dampak limbah plastik, dari pihak pemerintah dan diri pribadi perorangan harus saling menyadari. Pemerintah harus membuat tempat sampah di setiap sisi kota. Dan setiap individu juga harus mempunyai kesadaran tentang membuang sampah. Jangan campur sampah plastik dengan sampah yang bisa di daur ulang. Tempatkan sampah plastik pada tempat sampah yang telah ditentukan. Dan jangan membuang sampah plastik di tempat umum seperti di jalan, di sungai, di selokan, di parit, dan dimana sampah itu akan sangat berpotensi buruk bagi lingkungan.

6. Meningkatkan kegiatan seminar atau pertemuan yang membahas tentang daur ulang sampah plastik. Tentang metode cara pengolahan limbah plastik yang terbaru. Dan harapan kami, pemerintah ikut terlibat dalam sosialisasi daur ulang limbah plastik. Dan lembaga-lembaga negara atau swasta kami harap juga semakin gencar dalam membahas ancaman limbah plastik terhadap lingkungan hidup.

\section{Metode Pelaksanaan Kegiatan}

Pendekatan utama yang digunakan dalam merancang sistem pengelolaan sampah plastik dan pemanfaatan limbah plastic menjadi produk baru adalah konsep Ergonomi Total yang merupakan integrasi antara Ergonomi Makro dan Ergonomi Mikro. Tahap pertama yang dilakukan dalam penelitian ini adalah indentifikasi dan penelitian awal. Penelitian awal adalah 
mempelajari kondisi existing dari sistem pengelolaan sampah plastik di Karawang. Mulai dari aktivitas-aktivitas inti pengelolaan sampai pada operasional pengelolaan.

Kemudian dilakukan indentifikasi terhadap kekurangan atau permasalahanpermasalahan yang terjadi pada pengelolaan sampah plastik. Indentifikasi permasalahan dilakukan dengan menyebarkan sejumlah kuisioner terhadap 50 responden yaitu masyarakat yang berada dilingkar kampus UBP Karawang untuk mengetahui tingkat kesadaran dan pengetahuan masyarakat mengenai sampah dan sampah plastik khususnya.

\section{Peserta Kegiatan}

Yang menjadi peserta dalam kegiatan pengabdian pada masyarakat ini adalah masyarakat dilingkar kampus UBP di kampong Kaum Desa Puseurjaya Kecamatan Telukajmbe Timur Karawang, dengan jumlah peserta sebanyak 50 terdiri dari sebanyak 36 orang perempuan dan 14 orang laki-laki, daftar nama peserta kegiatan sebagai berikut :

\begin{tabular}{|l|l|l|l|l|}
\hline No & \multicolumn{1}{|c|}{ Nama } & L/P & Usia & \multicolumn{1}{c|}{ Pekerjaan } \\
\hline 1 & SITI MARHAMAH & $\mathrm{P}$ & 52 & IBU RUMAHTANGGA \\
\hline 2 & ACIH BINTI SYAH & $\mathrm{P}$ & 48 & IBU RUMAH TANGGA \\
\hline 3 & RATNA JUWITA & $\mathrm{P}$ & 24 & KARYAWATI SWASTA \\
\hline 4 & ENDANG JUWARSIH & $\mathrm{P}$ & 38 & KARYAWATI SWASTA \\
\hline 5 & HALIMAH JUNIARTI & $\mathrm{P}$ & 43 & IBU RUMAHTANGGA \\
\hline 6 & SARTIKA & $\mathrm{P}$ & 45 & IBU RUMAHTANGGA \\
\hline 7 & ENCIH & $\mathrm{P}$ & 51 & IBU RUMAHTANGGA \\
\hline 8 & ANIH & $\mathrm{P}$ & 50 & IBU RUMAH TANGGA \\
\hline 9 & MIMIN AMINAH & $\mathrm{P}$ & 48 & IBU RUMAH TANGGA \\
\hline 10 & AYU JUANDA & $\mathrm{P}$ & 38 & KARYAWATI SWASTA \\
\hline 11 & JUNIARSIH & $\mathrm{P}$ & 29 & KARYAWATI SWASTA \\
\hline 12 & MARTINAH & $\mathrm{P}$ & 38 & IBU RUMAHTANGGA \\
\hline 13 & HILDA HIKAYATI & $\mathrm{P}$ & 47 & KARYAWATI SWASTA \\
\hline 14 & UCU HALIMAH & $\mathrm{P}$ & 48 & IBU RUMAHTANGGA \\
\hline 15 & ANAH SUHANAH & $\mathrm{P}$ & 46 & IBU RUMAHTANGGA \\
\hline 16 & IDA RATNANINGSIH & $\mathrm{P}$ & 49 & KARYAWATI SWASTA \\
\hline 17 & RINA KURNIASIH & $\mathrm{P}$ & 44 & IBU RUMAHTANGGA \\
\hline 18 & NINA NURHASANAH & $\mathrm{P}$ & 45 & IBU RUMAHTANGGA \\
\hline 19 & ENCOP SOFIANTI & $\mathrm{P}$ & 45 & KARYAWATI SWASTA \\
\hline 20 & ANAH DAHLIANTI & $\mathrm{P}$ & 44 & KARYAWATI SWASTA \\
\hline 21 & ENDANG RATNANINGSIH & $\mathrm{P}$ & 52 & IBU RUMAHTANGGA \\
\hline 22 & SRI MARYANI & $\mathrm{P}$ & 51 & IBU RUMAHTANGGA \\
\hline 23 & NUNUNG NURHASANAH & $\mathrm{P}$ & 42 & IBU RUMAHTANGGA \\
\hline 24 & ELA WAELA & $\mathrm{P}$ & 60 & IBU RUMAHTANGGA \\
\hline 25 & BIHADNINGSIH & $\mathrm{P}$ & 68 & IBU RUMAHTANGGA \\
\hline 26 & SRI WATINI & $\mathrm{P}$ & 43 & IBU RUMAHTANGGA \\
\hline 27 & SANTI & $\mathrm{P}$ & 52 & IBU RUMAHTANGGA \\
\hline & & & & \\
\hline
\end{tabular}




\begin{tabular}{|l|l|l|l|l|}
\hline 28 & SISKA & $\mathrm{P}$ & 38 & KARYAWATI SWASTA \\
\hline 29 & ROHAYATI & $\mathrm{P}$ & 42 & IBU RUMAHTANGGA \\
\hline 30 & KOKOM KOMARIAH & $\mathrm{P}$ & 40 & IBU RUMAHTANGGA \\
\hline 31 & KURNAESIH & $\mathrm{P}$ & 39 & IBU RUMAHTANGGA \\
\hline 32 & SITI KOMALASARI & $\mathrm{P}$ & 42 & IBU RUMAHTANGGA \\
\hline 33 & NUNUNG NURHASANAH & $\mathrm{P}$ & 45 & IBU RUMAHTANGGA \\
\hline 34 & NILUH AYU & $\mathrm{P}$ & 53 & IBU RUMAHTANGGA \\
\hline 35 & RAHMATIANI DEWI & $\mathrm{P}$ & 31 & KARYAWATI SWASTA \\
\hline 36 & FARIDA & $\mathrm{P}$ & 28 & KARYAWATI SWASTA \\
\hline 37 & ASEP RAHMAT & $\mathrm{L}$ & 45 & WIRASWASTA \\
\hline 38 & ANDI SUTARDI & $\mathrm{L}$ & 38 & WIRASWASTA \\
\hline 39 & MAMAN ROSMANA & $\mathrm{L}$ & 53 & KARYAWAN SWASTA \\
\hline 40 & KARDI & $\mathrm{L}$ & 49 & KARYAWAN SWASTA \\
\hline 41 & KARYANA & $\mathrm{L}$ & 50 & WIRASWASTA \\
\hline 42 & MAMAT ITOK & $\mathrm{L}$ & 53 & WIRASWASTA \\
\hline 43 & SUDRAJAT & $\mathrm{L}$ & 48 & WIRASWASTA \\
\hline 44 & WAWAN HERMAWAN & $\mathrm{L}$ & 44 & KARYAWAN SWASTA \\
\hline 45 & SURYANA & $\mathrm{L}$ & 54 & WIRASWASTA \\
\hline 46 & MUHAMMAD & $\mathrm{L}$ & 38 & KARYAWAN SWASTA \\
\hline 47 & UJANG RAHMAN & $\mathrm{L}$ & 42 & KARYAWAN SWASTA \\
\hline 48 & ASEP KURNIA & $\mathrm{L}$ & 43 & KARYAWAN SWASTA \\
\hline 49 & AGUS HENDRIYANA & $\mathrm{L}$ & 32 & WIRASWASTA \\
\hline 50 & SUPRAPTO & $\mathrm{L}$ & 51 & WIRASWASTA \\
\hline SumASTASA & & & \\
\hline
\end{tabular}

Sumber : Penulis, 2018

\section{Alat Analisis}

Dalam kegiatan ini disebarkan kuisioner yang harus diisi oleh para peserta pada pelaksanaan kegiatan, hal ini dilakukan untuk mengetahui sejauh mana pemahaman peserta mengenai dampak sampah dan bahayanya bagi lingkungan masyarakat, selain itu juga kuisioner juga mengukur bagaimana minat dan respon masyarakat terhadap upaya alternative dalam pemanfaatan limbah plastic sebagai upaya kegiatan ekonomi kreatif masyarakat.

Berikut ini adalah rangkaian pertanyaan yang disampaikan kepada para peserta, terdiri dari 5 pertanyaan yang harus diisi dengan menggunakan pernyataan tertulis, hal ini dilakukan agar masyarkat dapat menyampaikan bagaimana perspektif mereka mengenai kondisi yang mereka alami dalam keseharian berkaitan dengan sampah dan limbah plastic

\begin{tabular}{|l|l|}
\hline No & \multicolumn{1}{c|}{ Pertanyaan } \\
\hline 1 & Bagaimana pendapat anda tentang sampah rumah tangga dilingkungan anda \\
\hline 2 & Menurut anda berbahayakah sampah bagi lingkungan \\
\hline 3 & Bagaimana menurut anda peran masyarakat dalam pengelolaan sampah \\
\hline 4 & $\begin{array}{l}\text { Bagaimana menurut anda peran pemerintah daerah dalam menangani permasalahan } \\
\text { sampah }\end{array}$ \\
\hline 5 & Bagaimana cara pengelolaan sampah yang baik menurut warga \\
\hline
\end{tabular}


$6 \quad$ Bagaimana upaya daur ulang sampah yang anda ketahui

$\begin{array}{ll}7 & \text { Perlukah ada pelatihan tentang pengelolaan sampah menjadi sebuah produk }\end{array}$

Pertanyaan yang diajukan kepada peserta kemudian dikumpulkan dan dikelompokkan berdasarkan kesamaan pandangan dan persepsi mereka mengenai objek yang dipertanyakan, kemudian diberikan pembobotan persentase rata-rata jawaban yang memiliki persepsi yang sama, kemudian diberikan kesimpulan mengenai setiap pertanyaan tersebut.

\section{Hasil dan Pembahasan}

Berdasarkan dari pengamatan awal dari form isian daftar hadir peserta perempuan diketahui bahwa jumlah peserta terdiri dari Perempuan dengan status tidak bekerja (sebagai ibu rumah tangga) dan perempuan dengan status bekerja sebagai karyawati perusahaan swasta, sedangkan laki-laki terdiri dari wiraswasta dan karyawan swasta, sehingga data tersbut dapat disajikan dalam table sebagai berikut

Tabel Data Peserta

\begin{tabular}{|l|c|c|c|}
\hline \multicolumn{1}{|c|}{ Jenis Kelamin } & Bekerja & Tidak & Jumlah \\
\hline Perempuan & 11 & 25 & 36 \\
\hline Laki-Laki & 6 & 8 & 14 \\
\hline Jumlah & 17 & 33 & 50 \\
\hline
\end{tabular}

Sumber : Data diolah, 2018

Dari data di atas diketahui bahwa sebanyak 25 orang perempuan dengan rata-rata usia lebih dari 40 tahun statusnya tidak bekerja, tidak memiliki penghasilan tetap, 3 orang diantaranya membuka usaha dagang makanan paruh waktu kemudian perempuan yang bekerja diperusahaan swasta sebanyak 11 orang. Sedangkan untuk Laki-laki yang bekerja sebanyak 6 orang, berprofesi sebagai wiraswasta sebanyak 8 orang sehingga jumlah seluruh peserta yang hadir dalam kegiatan tersebut sebanyak 50 orang.

Dari data isian peserta juga diketahui bahwa rata-rata peserta mengenyam pendidikan formal dengan data sebagai berikut :

1. Lulusan D3 sebanyak 1 orang

2. Lulusan SLTA sederajat sebanyak 43 orang

3. Lulusan SLTP sederajat sebanyak 6 orang 
Kemudian dari data isian pertanyaan yang disebarkan kepada peserta dapat disusun laporannya dalam table sebagai berikut :

\begin{tabular}{|c|c|c|}
\hline No & Pertanyaan & Jawaban \\
\hline 1 & $\begin{array}{l}\text { Bagaimana pendapat anda tentang } \\
\text { sampah rumah tangga dilingkungan } \\
\text { anda }\end{array}$ & $\begin{array}{l}\text { Umumnya peserta menyatakan bahwa } \\
\text { mereka merasa kesulitan untuk membuang } \\
\text { sampah, setiap hari sampah yang dihasilkan } \\
\text { dimasing-masing keluarga cukup banyak, } \\
\text { umumnya sampah terdiri dari organic } \\
\text { sayuran, daun daunan, dan anorganik dari } \\
\text { sampah plastic (kantong keresek), setiap hari } \\
\text { sampah dibuang dihalaman rumah dan } \\
\text { dibakar, sebagian kecil membuangnya di } \\
\text { pinggir jalan, dan dipinggir sungai. }\end{array}$ \\
\hline 2 & $\begin{array}{l}\text { Menurut anda berbahayakah sampah } \\
\text { bagi lingkungan }\end{array}$ & $\begin{array}{l}\text { Umumnya seluruh peserta menyadari bahwa } \\
\text { sampah sangat berbahaya bagi lingkungan } \\
\text { dan kesehatan, selain itu sampah bisa } \\
\text { menimbulkan pencemaran lingkungan } \\
\text { berbau tidak sedap dan penyebab terjadinya } \\
\text { banjir serta berbagai penyakit bagi } \\
\text { masyarakat. }\end{array}$ \\
\hline 3 & $\begin{array}{l}\text { Bagaimana menurut anda peran } \\
\text { masyarakat dalam pengelolaan sampah }\end{array}$ & 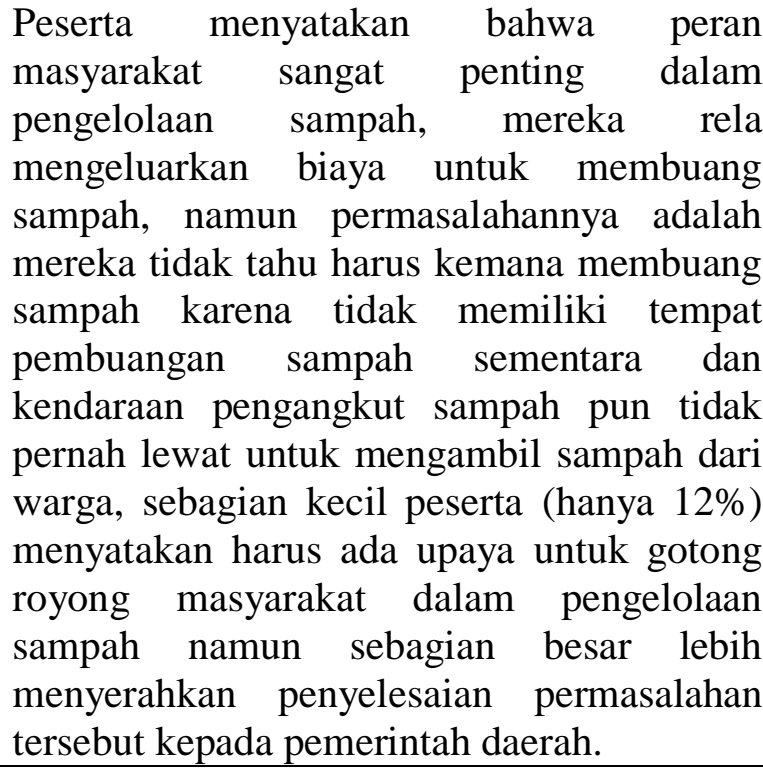 \\
\hline 4 & $\begin{array}{l}\text { Bagaimana menurut anda peran } \\
\text { pemerintah daerah dalam menangani } \\
\text { permasalahan sampah }\end{array}$ & $\begin{array}{l}\text { Peserta menyatakan bahwa Pemerintah } \\
\text { daerah harus menyediakan tempat } \\
\text { pembuangan sampah dan teknik pengelolaan } \\
\text { sampah yang lebih baik agar warga } \\
\text { masyarakat tidak kesulitan membuang } \\
\text { sampah, pemerintah dinilai memiliki peran } \\
\text { dan tanggungjawab yang sangat besar dalam } \\
\text { mengatasi permasalahan sampah, karena } \\
\text { warga masyarakat tidak mungkin membuang } \\
\text { sampah langsung ke tempat pembuangan } \\
\text { sampah akhir karena jaraknya yang cukup }\end{array}$ \\
\hline
\end{tabular}




\begin{tabular}{|c|c|c|}
\hline & & jauh dan ongkosnya yang mahal. \\
\hline 5 & $\begin{array}{l}\text { Bagaimana cara pengelolaan sampah } \\
\text { yang baik menurut warga }\end{array}$ & $\begin{array}{l}\text { Sebagian warga cenderung tidak mengetahui } \\
\text { dengan pasti bagaimana pengelolaan sampah } \\
\text { yang harus dilakukan (ditunjukkan dengan } \\
\text { sedikit pernyataan yang dibuat oleh peserta) } \\
\text { sebagian besar menyatakan bahwa tidak } \\
\text { pernah mendapatkan informasi dan arahan } \\
\text { dari pihak pemerintah daerah mengenai } \\
\text { bagaimana pengelolaan sampah di } \\
\text { masyarakat, sehingga umumnya mereka } \\
\text { secara rutin membuang sampah pada tempat } \\
\text { yang mereka anggap tepat untuk membuang } \\
\text { sampah }\end{array}$ \\
\hline 6 & $\begin{array}{l}\text { Bagaimana upaya daur ulang sampah } \\
\text { yang anda ketahui }\end{array}$ & $\begin{array}{l}\text { Daur ulang sampah plastic yang diketahui } \\
\text { oleh warga hanya sebatas pada usaha } \\
\text { pengepul sampah plastic bernilai ekonomis } \\
\text { seperti botol air minum dalam kemasan dan } \\
\text { jenis plastic lain (umumnya menunjukkan } \\
\text { pada limbah plastic industry) yang memiliki } \\
\text { nilai ekonomi yang cukup tinggi, sebagian } \\
\text { besar tidak memahami tentang teknik daur } \\
\text { ulang }\end{array}$ \\
\hline 7 & $\begin{array}{l}\text { Perlukah ada pelatihan } \\
\text { pengelolaan sampah menjadi } \\
\text { produk }\end{array}$ & $\begin{array}{l}\text { Seluruh peserta merasa perlu diadakan } \\
\text { kegiatan pelatihan mengenai bagaimana } \\
\text { mengolah limbah plastic hingga } \\
\text { menghasilkan produk yang memiliki nilai } \\
\text { jual, sehingga mereka memiliki keahlian } \\
\text { dalam memanfaatkan limbah plastic } \\
\text { sehingga diharapkan dapat menghasilkan } \\
\text { jenis usaha baru yang memberikan } \\
\text { tambahan penghasilan bagi masyarakat. }\end{array}$ \\
\hline
\end{tabular}

Sumber : Peneliti, diolah 2018

Pembahasan

Dari hasil kegiatan penyuluhan terhadap masyarakat yang dilakukan diketahui bahwa masyarakat dilingkar kampus UBP menyadari betapa berbahayanya sampah bagi lingkungan mereka, baik sampah organic maupun sampah non organic, mereka meyakini bahwa sampah menimbulkan masalah yang jauh lebih besar apabila tidak dikelola dengan benar, namun demikian sebagian besar masyarakat merasa bahwa intensitas penyuluhan terhadap masyarakat mengenai program penanggulangan sampah baik dari pemerintah daerah maupun lembaga lain dinilai masih sangat jarang, sehingga banyak masyarakat yang tidak memahami menganai cara pengelolaan sampah. 
Selain itu ketersediaan sarana dan prasarana pembuangan sampah dilingkungan masyarakat masih sangat sedikit sekali, sehingga masyarakat kebingungan kemana mereka harus membuang sampah, hal ini yang menyebabkan masyarakat sekitarnya hanya membakar sampah dihalaman rumah, atau bahkan membuangnya di pinggir kali citarum.

\section{Pemberian Materi Pelatihan Pemanfaatan Limbah Plastik untuk Ekonomi Kreatif}

Dalam pelatihan ini masyarakat diberikan beberapa contoh bagaimana menghasilkan berbagai produk dari pemanfaatan limbah plastic menjadi produk bernilai ekonomis dan memiliki nilai jual yang cukup diminati oleh masyarkat lainnya.

Dalam pelatihan tersebut setiap peserta diberikan bahan-bahan yang digunakan untuk membuat hasil karya, produk yang akan dibuat dalam pelatihan ini adalah :

1. Kantong cantik dari plastic bekas kemasan sabun deterjen dan lain-lain

2. Wadah aksesoris dan alat tulis dari bekas botol plastic ukuran 1 liter

\section{Alat dan bahan yang dibutuhkan untuk membuat kantong :}

1. 4 bungkus Bekas kemasan sabun deterjen berbagai merk ukuran $450 \mathrm{ml}$ dengan corak yang sama ( 2 buah untuk lapisan depan dan belakang, 2 buah untuk lapisan kiri dan kanan)

2. Gunting

3. $50 \mathrm{~cm}$ bisban untuk tali tas ukuran $3 \mathrm{~cm}$

4. 1 meter bisban ukuran $2 \mathrm{~cm}$

5. Retsleting atau dapat menggunakan perekat $4 \mathrm{~cm}$

6. Jarum dan benang jahit (sebaiknya menggunakan mesin jahit agar lebih cepat)

7. Furing/Kain lapisan tas

8. Kain renda penghias

Alat dan bahan yang dibutuhkan untuk membuat wadah kancing atau wadah aksesoris :

1. Botol bekas minuman soft drink ukuran 1 liter

2. Lem Bakar

3. Glue gun

4. Retsletting kecil

5. Aksesoris temple

Cara membuat kantong dari bekas kemasan deterjen 
1. bersihkan plastic dari noda dan kotoran untuk membersihkannya dapat menggunakan kertas tisu, namun jika sulit anda bias merendamnya dengan menggunakan air hangat

2. gunting dua buah kemasan dengan ukuran yang diinginkan, usahakan potongan kedua kemasan plastic memiliki ukuran yang sama

3. gunting dua kemasan lain (untuk sisi kiri dan kanan) menjadi dua bagian dengan lebar sekitar $7 \mathrm{~cm}$

4. pasang dan jahit perekat / retsleting untuk lebih cepat dilakukan dengan menggunakan mesin jahit, pada bagian depan dan belakang tas

5. pasang dan jahit bisban dengan lebar $3 \mathrm{~cm}$ pada bagian permukaan plastic bagian depan dan belakang untuk tali tas

6. pasang dan jahit renda katun sekaligus bisban ukuran $2 \mathrm{~cm}$ pada sisi atas lembar kemasan plastic, lakukan langkah ini pada kemasan plastic untuk bagian depan dan belakang

7. sambungkan kedua kemasan yang telah dipotong dengan ukuran $7 \mathrm{~cm}$ (untuk sisi kiri dan kanan) sehingga membentuk lembaran yang panjang

8. hubungkan dan sambungkan dengan menggunakan mesin jahit bagian nomor 7 dengan lembar plastic untuk bagian depan dan belakang

9. kemudian pasang bisban pada seluruh tepi

10. jadihal sebuah tas yang mungil dan cantik berbahan dasar bekas kemasan plastik

\section{Cara Membuat Wadah aksesoris dan alat tulis dari Botol Bekas}

potong dan buang bagian atas botol karena bagian ini tidak digunakan. Bagian bawah botol dapat dipotong dan disesuaikan dengan panjang wadah alat tulis yang diinginkan. Selanjutnya, gunakan lem plastik untuk merekatkan resleting pada bagian botol. Hasilnya juga bisa dipercantik dengan memberikan cat plastic dan menghiasnya dengan sticker atau aksesoris lain yang disesuaikan dengan selera

Kini tak perlu lagi mengeluarkan biaya untuk membeli tempat pensil baru, bahkan kreasi ini bisa dijadikan sebagai hadiah untuk adikmu atau teman-temanmu. Sangat mudah dan unik

\section{Kesimpulan}

Kegiatan penyuluhan mengenai dampak dan resiko dari sampah anorganik kepada masyarakat diseputar kampus memberikan efek positif terhadap peningkatan pemahaman mereka mengenai bagaimana masyarakat harus melakukan pengelolaan dengan baik, terutama dalam 
upaya memilah dan memisahkan sampah organic dan anorganik, hal ini tentu saja harus terus menerus ditingkatkan dengan intensitas yang lebih banyak baik oleh lembaga pendidikan terutama oleh pemerintah daerah.

\section{Sumber Pustaka}

Darsono, V. 2005. Upaya Pengelolaan Sampah Perkotaan. Jurnal Teknologi Industri IX, 3 (Juli):247-252

Damanhuri, Enri. Tri Padmi. 2010. Pengelolaan Sampah. Program Studi Teknik Lingkungan Fakultas Teknik Sipil dan Lingkungan Institut Teknologi Bandung.

Irma Hardi Pratiwi, Sritomo Wignjosoebroto, dan Dyah Santhi Dewi 2006. SISTEM PENGELOLAAN SAMPAH PLASTIK TERINTEGRASI DENGAN PENDEKATAN ERGONOMI TOTAL GUNA MENINGKATKAN PERAN SERTA MASYARAKAT (STUDI KASUS : SURABAYA) artikel diakses pada tanggal 27/01/2018 melalui alamat http://personal.its.ac.id/files/pub/2892m_sritomo-ie-Makalah\%20TA\%20Irma.pdf

Karwowski, Waldemar. 2005. Ergonomics and Human Factors: The Paradigms for science, engineering, design, Technology, and Management of Human-Compatible Systems. USA:Ergonomics (in press). 
Yayasan ULI Peduli dan LP3M ITS. 2006. Studi Rantai Post Consumer Waste. Laporan Akhir. Lembaga Penelitian dan Pengabdian Pada Masyarakat ITS, Surabaya.

Yudoko, Gatot. 2002. Municipal Solid Waste Planning and Management in Developing Countries: A State-of-The-Art and Implications for Further Research. Jurnal TMI 22 (3): $15-34$.

Tim Labfor Polri Ambil Sampel Limbah Plastik di Karawang untuk Dicek Kandungannya Artikel Kompas.com https://regional.kompas.com/read/2018/01/19/19312461/timlabfor-polri-ambil-sampel-limbah-plastik-di-karawang-untuk-dicek. Penulis Kontributor Karawang, Farida Farhan, diakses pada 12/02/2018

Anti Limbah Plastik, http://www.angelfire.com/indie/shefoughtbravely/sejarah.htm diunggah pada $18 / 01 / 2018$

http://irfanweb.com/2012/arti-7-simbol-segitiga-pada-plastik

https://www.facebook.com/notes/ordinasry-person/arti-lambang-segitiga-pada-kemasanplastik/10150826583535597

http://desxripsi.blogspot.com/2012/04/kenali-tanda-segitiga-pada-botoluntuk.html\#axzz2aIIH7NbT

http://rsud.purbalinggakab.go.id/berita/item/76-arti-simbol-pada-botol-plastik.html

https://www.makeit-loveit.com/no-sew-zipper-cases-from-old-soda-or-water-bottles

http://www.rmoljabar.com/read/2017/07/09/48046/Pasca-Lebaran-Volume-Sampah-diKarawang-Naik-45-Persen- 